\title{
WORK STRESS AMONG UNIVERSITY TEACHERS: GENDER AND POSITION DIFFERENCES
}

\author{
Ana SLIŠKOVIĆ ${ }^{1}$ and Darja MASLIĆ SERŠIĆ ${ }^{2}$ \\ Department of Psychology, University of Zadar, Zadar', Department of Psychology, Faculty of Humanities and Social \\ Sciences, University of Zagreb, Zagreb², Croatia \\ Received in July 2011 \\ CrossChecked in August 2011 \\ Accepted in September 2011
}

\begin{abstract}
The aim of this study was to investigate exposure to stress at work in university teachers and see if there were differences between men and women as well as between positions. The study was carried out online and included a representative sample of 1,168 teachers employed at universities in Croatia. This included all teaching positions: assistants (50\%), assistant professors (18\%), associate professors (17\%), and full professors (15\%). Fifty-seven percent of the sample were women. The participants answered a questionnaire of our own design that measured six groups of stressors: workload, material and technical conditions at work, relationships with colleagues at work, work with students, work organisation, and social recognition and status. Women reported greater stress than men. Assistant professors, associate professors, and full professors reported greater stress related to material and technical conditions of work and work organisation than assistants, who, in turn, found relationships with colleagues a greater stressor. Full professors, reported lower exposure to stress at work than associate professors, assistant professors, and assistants.
\end{abstract}

KEY WORDS: assistants, assistant professors, associate professors, full professors, gender differences, stressors, work environment, university teachers

The work of scientists and university teachers has largely changed recently. Thorsen (1) was among the first to observe that the occupation of academics had lost the characteristics for which it was traditionally considered stress-free and beneficial for work wellbeing and he determined that the quantity of work rather than its quality had become a source of stress for the members of the academic community. In recent years, many other authors (2-6) have confirmed this increasing pressure on university teachers, which is a result of a change in the policy and social status of higher education. The growing number of students and teachers and stronger connections with industry make the academic community less isolated and elite, and the working conditions at universities are becoming similar to those of other professions.
Work overload is perceived as workload beyond the scope of statutory requirements of a position (1-4) and as time pressure caused by colliding teaching, research, and administrative duties $(1,2,5,6)$.

Along with the work overload in terms of quantity, all the domains of the teachers' work in higher education are becoming more demanding. This primarily refers to the research domain, because the teacher is now required to possess entrepreneurial skills to obtain funding (7), and to the increasing pressure to publish $(2,7)$. According to Gillespie et al. (5) the "publish or perish" imperative very often has a counterproductive effect, as it lowers the working morale of university teachers. In addition, teachers work with an increasing number of students, who are also more demanding (5); they have to adapt to ever 
changing curricula (8), and implement newly introduced quality assurance procedures $(7,9)$. And while teachers have to keep abreast with rapid technological advances in all aspects of their work, administrative support is being cut down so that a substantial amount of administrative work is left for them to do.

Gillespie et al. (5) report that teachers perceive the under-funding of universities and the lack of human and material resources as the major obstacles to improved work efficiency and quality standards. They also see their autonomy and control downsized $(5,7)$ and are dissatisfied with bureaucratic management based on free market values and with the existing organisation of work (2). Job insecurity and a lack of promotion opportunities $(2,5)$, poor interpersonal relationships, particularly the lack of support from colleagues and/or superiors (10), and the feeling that their work is not adequately recognised and paid (5, 6) still further lower the morale of university teachers.

Several recent studies have examined work-life imbalance as a source of stress in academic staff $(4$, $6,7,11,12)$. Given the increasing work demands, due to which university teachers are forced to work evenings and weekends, the boundary between work and private life becomes blurred, and for most of them the level of work-life balance is far below desired. The encroachment of the work domain on the private one does not occur only because of the lack of physical boundaries between these two domains, but also because of the psychological commitment to work, which interferes with the other roles, does not allow for relaxation during free time, and disrupts sleep. Kinman and Jones (12) noted that teachers who perceived less control over work, schedule inflexibility, and less support from their superiors, experienced a higher level of work-life imbalance, which is also connected with the lower levels of psychological wellbeing, job dissatisfaction, and the intention of giving up the academic career.

Beside working conditions, other characteristics of this profession have also changed. In comparison with other sectors, the number of people working in science and higher education has increased, especially of women. Most research indicates a greater vulnerability of women when we talk about the experiences and consequences of stress at work in university teachers. This means that women employed in institutions of higher education experience higher levels of both work and family stress than men (13-15) and that women have more often consider leaving the job due to stress (13). Women in higher education more often report work/home imbalance as an important source of stress and experience more intense and increased pressure to publish scientific papers $(2,16)$.

In contrast, some studies show no differences between men and women in the perception (17) or consequences of exposure to stressors (18-20). Some even report sources of stress that men experience more intensely than women, such as organisational structure and climate, inadequate style of management at university/college, or changes that reduce participation in decision making, the level of autonomy, and control over work (2). However, it might be a consequence of different positions that men and women have, as women less often have senior positions with permanent contracts and greater power $(21,22)$.

One traditional feature of work in organisations of higher education that may favour stress is the highly hierarchical system of power, dominated by the power distance culture (23). Given the typology of power which was developed by French and Raven in 1960 (24), the hierarchical structure of higher education is based on greater legitimate power of teachers in higher positions. Legitimate power stems from the formal authority/position. As the advancement to higher academic positions is partly based on scientific performance, legitimate power may partly stem from the expert power. Expert power is based on specific knowledge and experience. The amount of power, the level of autonomy, work content and job security markedly separate two groups of staff: assistants and professors (assistant professors, associate, and full professors). These positions go with different stressors and with different exposure to stressors that are common for both groups.

Several studies report higher levels of stress (25, $26)$ and lower job satisfaction $(20,27,28)$ in teachers at junior positions. These could be explained by lower control, autonomy, salary and greater job insecurity in junior teachers. In contrast, O'Laughlin and Bischoff (15) found no significant differences in the perception of stress between positions, while Arnold et al. (29) found higher levels of stress in senior scientific and teaching positions. They explained these differences by greater academic and administrative requirements needed for advancement. Vagg et al. (16) compared university employees and workers in industry and found that stress at higher organisational levels was related to making critical decisions and dealing with crisis situations, while at lower levels it 
Table 1 Position, gender, mean age, children to support, and average number of hours worked per week

\begin{tabular}{|c|c|c|c|c|c|c|c|c|c|c|c|c|c|c|}
\hline \multirow{3}{*}{ Position } & \multirow[b]{3}{*}{$\mathbf{N}$} & \multirow[b]{3}{*}{$(\%)$} & \multirow{2}{*}{\multicolumn{2}{|c|}{ Women }} & \multirow{3}{*}{$\frac{\text { Age }}{\text { Iean (SD) }}$} & \multirow{2}{*}{$\begin{array}{c}\text { Have } \\
\text { financially } \\
\text { dependent } \\
\text { children }\end{array}$} & \multicolumn{8}{|c|}{$\begin{array}{c}\text { Average number of hours worked } \\
\text { per week* }\end{array}$} \\
\hline & & & & & & & \multicolumn{2}{|c|}{$<35$} & \multicolumn{2}{|c|}{35 to 45} & \multicolumn{2}{|c|}{45 to 60} & \multicolumn{2}{|c|}{$>60$} \\
\hline & & & $\mathbf{n}$ & $(\%)$ & & $(\%)$ & $\mathbf{n}$ & $(\%)$ & $\mathrm{n}$ & $(\%)$ & $\mathrm{n}$ & $(\%)$ & n & $(\%)$ \\
\hline Full professor & 177 & $(15)$ & 76 & $(43)$ & $56.6(7.67)$ & $105 \quad(59)$ & 9 & $(5)$ & 52 & $(29)$ & 89 & $(50)$ & 26 & $(15)$ \\
\hline Associate professor & 173 & $(15)$ & 89 & $(51)$ & $48.1(7.21)$ & $117 \quad(68)$ & 9 & (5) & 34 & $(20)$ & 98 & $(57)$ & 29 & (17) \\
\hline Assistant professor & 217 & (19) & 132 & $(61)$ & $42.1(7.40)$ & $145 \quad(67)$ & 19 & (9) & 70 & $(32)$ & 99 & (46) & 27 & (12) \\
\hline Assistant & 601 & $(51)$ & 371 & $(62)$ & $31.0(5.09)$ & $155 \quad(26)$ & 87 & $(15)$ & 180 & $(45)$ & 269 & $(45)$ & 56 & $(9)$ \\
\hline All & 1168 & $(100)$ & 668 & (57) & $39.2(11.47)$ & $522 \quad(45)$ & 124 & (11) & 336 & (29) & 555 & $(48)$ & 138 & (12) \\
\hline
\end{tabular}

*The standard working week in Croatia is 40 hours.

was related to inadequate salary and lack of opportunity for advancement in either environment.

The aim of our study was to examine the pressures university teachers exposed at work. We were interested in the degree of the perceived presence of specific stressors at work, especially in the differences between men and women and different job positions. We presumed that, because of the traditional gender roles in society and competitive work environment, women would be more exposed to stress. We also presumed that because of the greater objective job insecurity and reduced possibility of control, employees at lower positions, assistants in particular, would be exposed to greater stress at work than assistant professors, associate and full professors.

\section{METHODS}

\section{Data collection}

For this study we posted a survey online for six weeks and invited academics to answer our questions, whose e-mail addresses had been posted on the official web sites of the four largest Croatian universities. Participation was voluntary and anonymous. Participants were given an opportunity to freely ask for additional information via e-mail.

\section{Sample}

Of the 5,269 academics invited to participate, $1,168$ responded ( $22 \%)$. Table 1 shows respondent profile by gender, age, child support, and the reported average number of working hours per week.

Of all respondents, $57 \%$ were women and made a far better sample than men ( $44 \%$ of the targeted population, chi-square $=74.67, \mathrm{df}=1, \mathrm{p}<0.01)$. Men and women in teaching positions were equally represented (43\% and $57 \%$, respectively). Women were significantly better represented among assistants ( $62 \%$ vs $38 \%$ of men, chi-square $=16.28, \mathrm{df}=1$, $\mathrm{p}<0.01)$.

The most represented was the assistant position (51\% among respondents, $46 \%$ of the targeted population; chi-square $=21.85, \mathrm{df}=1, \mathrm{p}<0.01$ ). Assistants without a doctorate made $42 \%$ of all respondents and those with a doctorate (senior assistants) $9 \%$. Both groups of assistants were employed on short-term contracts. Assistant professors made $19 \%$ and associate professors $15 \%$ of the respondents, and their representation corresponded to the targeted population. Full professors ${ }^{1}$ made $15 \%$ of the respondents. This position was significantly underrepresented in respect to the targeted population ( $15 \%$ vs. $21 \%$; chi-square $=8.75, \mathrm{df}=1, \mathrm{p}<0.01)$.

Most of the respondents were teachers employed at the University of Zagreb (58\%), followed by teachers from the Split and Osijek universities, who made $14 \%$ and $13 \%$, respectively. These percentages do not differ much from the targeted population.

\section{Instruments}

The on-line questionnaire we used consisted of questions grouped around the socio-demographic profile of the respondents such as gender, age, university or college of employment, academic degree, position, scientific field, total work experience, years of service at the university where they were currently employed, marital status, number of financially dependent children, and the age of the youngest dependent child. Two additional questions related to the total number of working hours per week and the reasons for overtime, where applicable.

${ }^{1}$ Full professor is the highest academic title in Croatia; the position is permanent and not subject to formal evaluation or re-election. 
The second group of 37 items was taken from the Questionnaire of Exposure to Stress at Work for University Teaching Staff that we recently designed for a doctoral thesis (30). The respondents had to score each item on a six-point scale, where "1" meant "this does not describe my job at all" and " 6 " meant "this perfectly describes my job". These items were organised around six groups of stressors in university teachers (30), as follows:

1. Material/technical working conditions (reliability index Cronbach's alpha=0.89); six items, such as: "Impossibility to purchase high-quality research equipment" and "Inadequate technical equipment for research or teaching".

2. Work with students (Cronbach's alpha $=0.82$ ); six items, such as: "Lack of interest and motivation in students" and "Poor student achievement".

3. Interpersonal relationships in the workplace (Cronbach's alpha $=0.88$ ); eight items, such as: "Supervisors have too much power to influence one's career" and "No help or support from the mentor".

4. Workload (Cronbach's alpha $=00.86$ ); seven items, such as: "General lack of time for research" and "Work - life imbalance".

5. Work organisation (Cronbach's alpha $=0.75$ ); five items, such as: "Too many meetings" and "Membership in too many committees and other bodies".

6. Social recognition and status (Cronbach's alpha $=0.75$ ) a source of stress related to the insufficient state funding of science; five items, such as: "Lack of government incentive for science", "Lower university salaries in relation to other colleagues of the same profession".

\section{Data analysis}

The positional differences in the assessment of exposure to stressors were analysed using one-way analysis of variance followed by Tukey HSD post-hoc tests, while gender differences were analysed using Student's $t$-test.

\section{RESULTS}

\section{Positional differences in exposure to stressors} at work

We found significant differences $(\mathrm{p}<0.01)$ between positions in assessing material and technical conditions, interpersonal relationships, workload, work organisation, and social recognition and status (Table 2 ). An exception was work with students ( $p>0.05$ ). In addition to one-way ANOVA, we used the Tukey HSD post-hoc test adapted to different sample sizes to determine which positions differed significantly from which positions. Material and technical conditions, workload, and social recognition and status showed the same pattern of differences between positions. Exposure to these stressors increased with hierarchy, reaching its peak at the position of assistant professor, and then it decreased (Figure 1, Table 2). Exposure to stress in interpersonal relationships reached its peak at the position of senior assistant, while stress from work organisation was similarly high among assistant professors, associate professors, and full professors (Figure 1, Table 2).
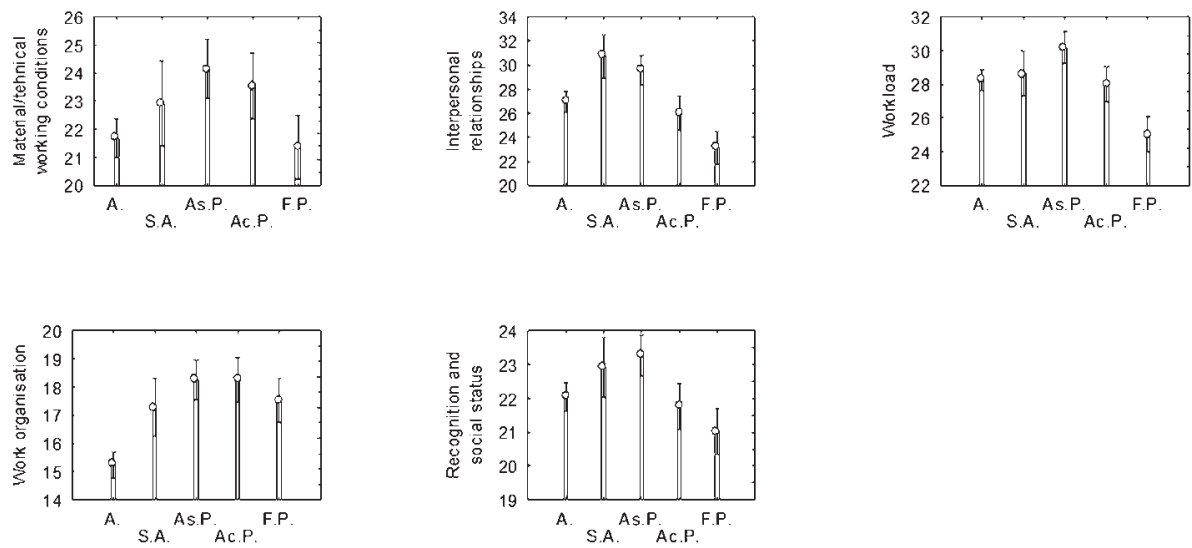

Figure 1 Stressor rating by university teachers at different positions $A .=$ assistants $(N=498) ; S . A .=$ senior assistants $(N=103) ;$ As. $P .=$ assistant professors $(N=217) ;$ Ac.P. $=$ associate professors $(N=173) ;$ F.P. $(N=177)=$ full professors

Stressor ratings $=$ average six-point scale scores . 
Table 2 Stressors as rated by teachers at different university positions

\begin{tabular}{|c|c|c|c|c|c|c|c|c|c|c|c|c|}
\hline \multirow{3}{*}{ Position } & \multicolumn{12}{|c|}{ Sources of stress } \\
\hline & \multicolumn{2}{|c|}{$\begin{array}{l}\text { Material- } \\
\text { technical } \\
\text { working } \\
\text { conditions }\end{array}$} & \multicolumn{2}{|c|}{$\begin{array}{l}\text { Work with } \\
\text { students }\end{array}$} & \multicolumn{2}{|c|}{$\begin{array}{l}\text { Interpersonal } \\
\text { relationships }\end{array}$} & \multicolumn{2}{|c|}{ Workload } & \multicolumn{2}{|c|}{$\begin{array}{c}\text { Work } \\
\text { organisation }\end{array}$} & \multicolumn{2}{|c|}{$\begin{array}{c}\text { Social } \\
\text { recognition } \\
\text { and status }\end{array}$} \\
\hline & M & SD & M & SD & M & SD & M & SD & M & SD & M & SD \\
\hline $\begin{array}{l}\text { Full } \\
\text { professor }\end{array}$ & 21.36 & 7.52 & 19.32 & 6.08 & 23.13 & 8.84 & 25.04 & 7.42 & 17.52 & 5.32 & 21.03 & 4.77 \\
\hline $\begin{array}{l}\text { Associate } \\
\text { professor }\end{array}$ & 23.55 & 7.30 & 20.56 & 5.91 & 25.97 & 8.85 & 27.98 & 7.25 & 18.26 & 5.68 & 21.76 & 4.57 \\
\hline $\begin{array}{l}\text { Assistant } \\
\text { professor }\end{array}$ & 24.15 & 7.56 & 20.86 & 5.87 & 29.57 & 9.35 & 30.16 & 6.61 & 18.25 & 4.98 & 23.27 & 4.28 \\
\hline $\begin{array}{l}\text { Senior } \\
\text { assistant }\end{array}$ & 22.92 & 7.93 & 20.93 & 6.14 & 30.71 & 10.29 & 28.64 & 7.49 & 17.29 & 5.42 & 22.91 & 4.62 \\
\hline Assistant & 21.68 & 8.03 & 20.38 & 6.18 & 26.94 & 9.53 & 28.26 & 6.97 & 15.25 & 5.33 & 22.05 & 4.67 \\
\hline $\begin{array}{l}\text { F-ratios } \\
(4 / 1163)\end{array}$ & \multicolumn{2}{|c|}{$5.67 * * *$} & \multicolumn{2}{|c|}{1.93} & \multicolumn{2}{|c|}{$16.17 * * *$} & \multicolumn{2}{|c|}{$13.13 * * *$} & \multicolumn{2}{|c|}{$18.89^{* * *}$} & \multicolumn{2}{|c|}{$13.13 * * *$} \\
\hline
\end{tabular}

$* * * p<0.01$

Stressor ratings $=$ average six-point scale scores

Gender differences in assessing stressors at work

Women on average reported greater exposure to stress at work (Table 3). Gender differences were the most pronounced for workload. Women in all positions assessed workload as a significantly stronger stressor than men. Unfavourable social recognition and status were also more prominent in women, save for full professors. Significant gender differences were also found in the assessment of interpersonal relationships for associate professors and assistant professors. Furthermore, exposure to unfavourable material and technical conditions was higher in women than men assistants, while women associate professors considered work organisation a greater stressor than their male colleagues. Generally, gender differences in subjective exposure to stressors were the most pronounced in associate professors.

\section{DISCUSSION}

Our study points to three findings: (1) most university teachers have to cope with excessive

Table 3 Stressors as rated by men and women at different university positions

\begin{tabular}{|c|c|c|c|c|c|c|c|c|c|c|c|c|c|}
\hline \multirow{3}{*}{ Position } & \multirow{3}{*}{ Gender } & \multicolumn{12}{|c|}{ Sources of stress } \\
\hline & & \multicolumn{2}{|c|}{$\begin{array}{l}\text { Material- } \\
\text { technical } \\
\text { working } \\
\text { conditions }\end{array}$} & \multicolumn{2}{|c|}{$\begin{array}{l}\text { Work with } \\
\text { students }\end{array}$} & \multicolumn{2}{|c|}{$\begin{array}{l}\text { Interper- } \\
\text { sonal } \\
\text { relation- } \\
\text { ships }\end{array}$} & \multicolumn{2}{|c|}{ Workload } & \multicolumn{2}{|c|}{$\begin{array}{c}\text { Work } \\
\text { organisation }\end{array}$} & \multicolumn{2}{|c|}{$\begin{array}{c}\text { Social } \\
\text { recognition } \\
\text { and status }\end{array}$} \\
\hline & & M & SD & M & SD & M & SD & M & SD & M & SD & M & SD \\
\hline \multirow{6}{*}{$\begin{array}{l}\text { Full } \\
\text { professor } \\
\text { Associate } \\
\text { professor } \\
\text { Assistant } \\
\text { professor }\end{array}$} & Wome & 21.88 & 7.44 & 18.67 & 6.21 & 23.36 & 8.92 & 26.32 & 7.52 & 17.79 & 5.20 & 21.70 & 4.28 \\
\hline & Men & 20.97 & 7.59 & 19.82 & 5.97 & 22.96 & 8.82 & 24.08 & 7.24 & 17.32 & 5.43 & 20.52 & 5.08 \\
\hline & Women & 24.13 & 6.97 & 20.75 & 6.05 & 28.41 & 8.61 & 28.96 & 7.53 & 19.42 & 5.05 & 22.80 & 4.37 \\
\hline & Men & 22.91 & 7.69 & 20.33 & 5.88 & 23.15 & 8.40 & 26.77 & 6.84 & 16.92 & 6.07 & 20.57 & 4.59 \\
\hline & Women & 24.74 & 7.59 & 20.96 & 6.10 & 30.73 & 9.37 & 31.05 & 6.21 & 18.74 & 4.80 & 23.89 & 3.99 \\
\hline & Men & 23.33 & 7.51 & 20.77 & 5.57 & 27.95 & 9.04 & 28.77 & 7.09 & 17.63 & 5.17 & 22.30 & 4.49 \\
\hline \multirow{2}{*}{ Assistant } & Women & 22.53 & 8.01 & 20.15 & 6.11 & 27.95 & 9.72 & 28.86 & 6.94 & 15.66 & 5.59 & 22.65 & 4.76 \\
\hline & Men & 20.78 & 7.90 & 20.98 & 6.25 & 26.82 & 9.70 & 27.40 & 7.19 & 15.43 & 5.04 & 21.41 & 4.47 \\
\hline
\end{tabular}

Significant differences are shadowed. Stressor ratings = average six-point scale scores. 
workload; (2) women report higher exposure to stressors at work, to workload in particular; (3) teachers in middle positions (assistant professors and associate professors) report the highest exposure to stressors, while full professors the lowest. It measured universal stressors that can be observed in different work settings and are not specific for university teachers (31). An exception is work with students, which includes relationships with students, their interest and motivation, and general student performance.

Over three quarters of the teachers reported working more than 40 hours a week, and almost $40 \%$ worked more than fifty hours a week. Similar findings were reported in other countries. Kinman and Jones (32) reported that $54 \%$ of British higher education teachers worked more than 45 hours a week, and $21 \%$ more than 55 hours. Most said they could not complete pending tasks within the regular 40-hour working time, which is the case in our study too. These findings do not support the conventional stereotype of the intrinsic commitment to work because of which scientists and university teachers neglect other life roles, but they rather indicate exposure to high workload, which can reduce their well-being and quality of performance at work.

Some workload stressors are directly related to the spilling over of work into the family and social domain. This is one of the reasons why this dimension reports great differences between men and women at certain positions. Similar trends are reported in Bradley and Eachus (14) and more recently O'Laughlin and Bischoff (15). They also showed that women university teachers reported a greater experience of pressure due to the work-life imbalance than their male counterparts. This is a consequence of traditional gender roles. Women who wish to commit themselves to work, have a greater price to pay than men when it comes to family obligations and homemaking. In transitional and developed Western European countries women still take care of the household and children more than their men, even though they work full time $(33,34)$. Earlier studies confirm this negative spilling over of work into the family and social domain as a significant source of stress in university teachers (4, $6,11,12)$.

Poor interpersonal relationships have been recognised as occupational stressors that threat psychological well-being of an individual (35); university teachers are no exception. This stressor implies poor relationships with superiors and/or mentors, and to a lesser degree with peers. Interpersonal relationships at universities are therefore ruled by the power system, that is, hierarchy or control. Our study clearly shows that assistants are find themselves more exposed to adverse interpersonal relationships than other positions, which largely stems from distancing $(36,37)$. Institutions of higher education all over the whole world often encourage this behavioural patterns (38).

Stressors such as unfavourable social recognition and status, material/technical working conditions and work organisation stem from unfavourable financial and social recognition of higher education. Similar to their colleagues all over the world, Croatian higher education teachers poorly rate the society's funding of science $(5,6)$ and experience this as a source of stress. The greatest pressure is experienced by teachers in the middle positions, primarily by assistant professors, who have recently obtained their doctorate and are beginning an independent scientific career. In general, material/technical conditions and work organisation issues affect professors more than they affect assistants. This is because professors feel a greater responsibility for the material and technical equipment, and therefore this stressor is generally more experienced in their work. They are also more exposed to stress arising from organisational weaknesses of the institution of which they are members, as expectations of professional advancement increase (29).

Full professors, men and women alike, reported the lowest level of exposure to stress at work. This could be related to the sense of security, autonomy, and power. This is not the case with lower positions, which offer less security, power, and autonomy.

In terms of social recognition and status, it seems that the state-proclaimed commitment to the advancement of science and education is not accompanied by a corresponding financial support. Teachers in higher education perceive poor social recognition and material/technical working conditions as characteristic stressors of their profession. These conditions impair the quality of their own work and may be the reason for society's disappointment with the academic community.

Interpersonal relationships are largely determined by the hierarchical system of power and control and are the greatest stressor for assistants. Strategies whose aim would be to increase the autonomy and control of work in this position should improve the experience of well-being and the quality of work. They should 
clearly define work roles, and set an effective system of goals and feedback (39). They should also take into account the growing number of women and their perception of greater workload as opposed to men. The academic community should take an affirmative position toward a balance between work and family/ social life.

Given that this study was an online survey, it may have its limitations. As only $22 \%$ responded, this raises the issue of how representative this sample is for a respective group. According to Galešić (40) one of the greatest limitations of online surveys is the auto-selection of participants. As our survey was about stress at work, it may have attracted respondents who felt more exposed to stress than the rest of their group. Even though the respondent sample did not significantly differ from the targeted sample in gender, position, and affiliation, teachers at lower positions are slightly over-represented, women in particular.

Another limitation is that we relied on subjective assessment. Future research should include more objective measures of workload and stress at work such as the number of teaching hours, mentorship, students, or subjects taught. This kind of a systematic analysis of the sources of stress at work should have preceded recent organisational changes in higher education institutions, which have not been planned out as well as they should have.

\section{CONCLUSION}

This study indicates that teachers in higher education are exposed to high levels of occupational stress, middle positions and women in particular. These findings need a confirmation by more objective parameters than self-assessment. A resulting systematisation could provide a firm ground for strategies that would improve conditions for teachers in higher education.

\section{REFERENCES}

1. Thorsen EJ. Stress in academe: What bothers professors? High Educ 1996;31:471-89.

2. Kinman G. Pressure Points: A survey into the causes and consequences of occupational stress in UK academic and related staff. London: Association of University Teachers 1998 [displayed 25 March 2011]. Available from http://www. ucu.org.uk/media/pdf/pressurepoints.pdf
3. Tytherleigh MY. What employers may learn from English higher education institutions: A fortigenic approach to occupational stress. J Ind Psychol 2003;29:101-6.

4. Tytherleigh MY, Webb C, Cooper CL, Ricketts C. Occupational stress in UK higher education institutions: a comparative study of all staff categories. High Educ Res Dev 2005;24:41-61.

5. Gillespie NA, Walsh M, Winefield AH, Dua J, Stough C. Occupational stress in universities: staff perceptions of the causes, consequences and moderators of stress. Work Stress 2001;15:53-72.

6. Barkhuizen N, Rothmann S. Occupational stress of academic staff in South African higher education institutions. S Afr J Psychol 2008;38:321-36.

7. Cownie F. Two jobs, two lives and a funeral: legal academics and work-life balance. Web Journal of Current Legal Issues Ltd. 2004 [displayed 25 March 2011]. Available from http:// webjcli.ncl.ac.uk/2004/issue5/cownie5.html

8. Parry J, Mathers J, Thomas H, Lilford R, Stevens A, Spurgeon P. More students, less capacity? An assessment of the competing demands on academic medical staff. Med Educ 2008:42:1155-65.

9. Winefield AH, Gillespie N, Stough C, Dua J, Hapuarachchi J, Boyd C. Occupational stress in Australian university staff: Results from a national survey. Int J Stress Manage 2003;10:51-63.

10. Narayanan L, Menon S, Spector PE. Stress in the workplace: a comparison of gender and occupations. J Organiz Behav 1999;20:63-73

11. Kinman G, Jones F. Effort-reward imbalance, overcommitment and work-life conflict: testing an expanded model. J Manag Psychol 2008;23:236-51.

12. Kinman G, Jones F. A life beyond work? Job demands, worklife balance, and wellbeing in UK academics. J Hum Behav Soc Environ 2008;17(1-2):41-60.

13. Blix AG, Cruise RJ, Mitchell BM, Blix GG. Occupational stress among university teachers. Educ Res 1994;36:15769.

14. Bradley J, Eachus P. Occupational stress within a U.K. higher education institution. Int J Stress Manage 1995;2:145-58.

15. O'Laughlin EM, Bischoff LG. Balancing parenthood and academia. Work/family stress as influenced by gender and tenure status. J Fam Issues 2005;26:79-106.

16. Vagg PR, Spielberger CD, Wasala CF. Effects of organizational level and gender on stress in the workplace. Int J Stress Manage 2002;9:243-61.

17. Tytherleigh MY, Jacobs PA, Webb C, Ricketts C, Cooper CL. Gender, health and stress in English university staff Exposure or vulnerability? Appl Psychol 2007;56:267-87.

18. Barnes LLB, Agago MO, Coombs WT. Effects of job-related stress on faculty intention to leave academia. Res High Educ 1998;39:457-69.

19. Lease SH. Occupational role stressors, coping, support, and hardiness as predictors of strain in academic faculty: an emphasis on new and female faculty. Res High Educ 1999;40:285-307.

20. Leung TW, Siu OL, Spector PE. Faculty stressors, job satisfaction and psychology distress among university teachers in Hong Kong: The role of locus of control. Int J Stress Manage 2000;7:121-38.

21. Doyle C, Hind P. Occupational stress, burnout and job status in female academics. Gend Work Organ 1998;5:67-82. 
22. Shaw S, Cassell C. "That's not how I see it": female and male perspectives on the academic role. Women Manage Rev 2007;22:497-515.

23. Hofstede G, Hofstede, G-J. Cultures and Organizations: Software of the Mind. New York: McGraw-Hill; 2004.

24. Muchinsky PM. Psychology Applied to Work. Belmont (CA): Wadsworth Publishing Company; 2006.

25. Kinman G. Pressure Points: A review of research on stressors and strains in UK academics. Educ Psychol 2001;21:47392.

26. Abouserie R. Stress, coping strategies and job satisfaction in university academic staff. Educ Psychol 1996;16:49-56.

27. Oshagbemi T. The influence of rank on the job satisfaction of organizational members. J Manage Psychol 1997;12:511 9.

28. Oshagbemi T. Personal correlates of job satisfaction: Empirical evidence from UK universities. Int J Soc Econ 2003;30:1210-32.

29. Arnold GL, Trice AG, Rosevear SG, McKinnon SA. Faculty stress: The influence of institutional characteristics. ERIC Collection of ASHE Annual Meeting Paper 1996 [displayed 25 March 2011]. Available at http://www.eric.ed.gov/PDFS/ ED405752.pdf

30. Slišković, A. Stres kod nastavnika u visokom obrazovanju u funkciji zahtjeva posla i radnog lokusa kontrole [Stress in the work of teachers in higher education in function of job demands and work locus of control, in Croatian] [PhD thesis] Zagreb: Zagreb University Faculty of Humanities and Social Sciences; 2010.

31. Williams S, Cooper CL. Measuring occupational stress: Development of the pressure management indicator. J Occup Health Psych 1998;3:306-21.
32. Kinman G, Jones F. Working to the limit: Stress and work-life balance in academic and academic related employees in the UK 2004 [displayed 25 March 2011]. Available at http:// www.ucu.org.uk/media/pdf/4/7/workingtothelimit.pdf

33. Jelušić J, Maslić Seršić D. Obiteljske i radne okolnosti kao prediktori ravnoteže obiteljskog i poslovnog života zaposlenih majki [Family and work context as predictors of family-work balance in employed mothers, in Croatian]. Suvrem Psihol 2005;8:23-36.

34. Greenhaus JH, Parasuraman S. The allocation of time to work and family roles. In: Nelson DL, Burke RJ, editors. Gender, work stress, and health: Current research issues. Washington (DC): American Psychological Association; 2002. p. 11528.

35. Cartwright S, Cooper CL. Coping in occupational settings. In: Zeidner M, Endler NS, editors. Handbook of coping: Theory, research, applications. New York (NY): John Wiley and Sons, Inc; 1996. p. 202-20.

36. Hofstede G. Culture's consequences: International differences in work-related values. Newbury Park (CA): Sage; 1980.

37. Payne R. Organizations as psychological environments. In: Warr P, editor. Psychology at work. London: Penguinin Books Ltd; 2002. p. 375-425.

38. White J, Weathersby R. Can universities become true learning organizations? The Learning Organization 2005;12:292-8.

39. O'Driscoll MP, Cooper CL. Job-related stress and burnout. In: Warr P, editor. Psychology at work. London: Penguinin Books Ltd; 2002. p. 203-29.

40. Galešić M. Anketna istraživanja preko interneta: Mogući izvori pogrešaka. [Online surveys: Possible sources of errors, in Croatian]. Druš Istraž 2005;14:297-320. 


\section{Sažetak}

\section{STRES U RADU SVEUČILIŠNIH NASTAVNIKA: RODNE I POZICIJSKE RAZLIKE}

Cilj rada bio je istražiti izloženost sveučilišnih nastavnika stresu u radu i ispitati postoje li razlike između muškaraca i žena te zaposlenika na različitim pozicijama u stupnju izloženosti i prirodi radnih stresora. Istraživanje je metodom on-line ankete provedeno na reprezentativnom uzorku od 1168 nastavnika zaposlenih na sveučilištima u Hrvatskoj. Obuhvaćene su bile sve znanstveno-nastavne pozicije: asistenti (51\%), docenti (19\%), izvanredni profesori (15\%) i redoviti profesori $(15 \%) .57 \%$ uzorka činile su žene. Primijenjen je Upitnik izloženosti stresu u radu za sveučilišne nastavnike (ISR-SN) koji sadržava 37 čestica i mjeri šest latentnih dimenzija izvora stresa: radno opterećenje, materijalne/tehničke uvjete rada, odnose na poslu, studente, organizaciju rada i društvene uvjete rada. Žene u odnosu prema muškarcima u prosjeku izvještavaju o većoj prisutnosti izvora stresa u svom poslu. Docenti, izvanredni i redoviti profesori u prosjeku procjenjuju veću prisutnost stresora vezanih uz materijalne/tehničke uvjete rada i organizaciju rada u odnosu na asistente koji, pak, u većoj mjeri procjenjuju prisutnost stresora vezanih uz međuljudske odnose. Redoviti profesori u prosjeku izvještavaju o manjoj izloženosti stresorima u svom poslu od izvanrednih profesora, docenata i asistenata.

KLJUČNE RIJEČI: asistenti, docenti, izvanredni profesori, redoviti profesori, rodne razlike, stresori, radna okolina, sveučilišni nastavnici

\section{CORRESPONDING AUTHOR:}

Ana Slišković

Department of Psychology, University of Zadar

Obala kralja Petra Krešimira IV, 2

23000 Zadar, Croatia

Email:aslavic@unizd.hr 